\title{
Infected Branchial Cleft Cyst Due to Neisseria meningitidis: An Unusual Presentation in a Pediatric Case
}

\author{
Neisseria meningitidise Bağlı Enfekte Brankial Yarık Kisti: Bir Pediatrik Olguda \\ Olağandışı Bir Sunum
}

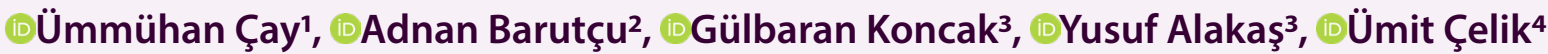 \\ 1Department of Pediatric Infectious Diseases, Cukurova University Medical Faculty, Adana, Turkey \\ 2Department of Pediatrics, Cukurova University Medical Faculty, Adana, Turkey \\ ${ }^{3}$ Department of Pediatrics, Adana City Research and Training Hospital, Adana, Turkey \\ ${ }^{4}$ Department of Pediatric Infectious Disease, Adana City Research and Training Hospital, Adana, Turkey
}

\begin{abstract}
Meningococcal disease, which is caused by Neisseria meningitidis ( $N$. meningitidis), may present clinically as meningococcemia, as meningitis, or with a mixed picture. A 3-year-old girl was admitted to our hospital with a tender, immobile, hard, hot and erythematous mass measuring $3 \times 4 \mathrm{~cm}$ on the left anterior part of the neck. The patient was diagnosed with branchial cleft cyst in the left side of the neck and regularly followed by an otolaryngologist since 6-month-old. The abscess culture grew N. meningitidis. Serogroup determination identified nongroupable Neisseria meningitidis. Infected branchial cleft cyst associated with $N$. meningitidis has rarely been reported, and to our knowledge, this is the second case in the literature. This demonstrates the importance of microbiologic identification, which plays a major role in the management of the patient. It should be noted that N.meningitidis can present with unusual clinical manifestations affecting all systems of the body; which indicates the importance of vaccination in vaccine-preventable diseases.
\end{abstract}

Keywords: Neisseria meningitidis, branchial cleft cyst, children

\section{ÖZ}

Neisseria meningitidisin ( $N$. meningitidis) neden olduğu meningokok hastalığı klinik olarak meningokoksemi, menenjit veya karışık bir tablo ile kendini gösterebilir. Boynun sol ön kısmında $3 \times 4 \mathrm{~cm}$ boyutlarında hassas, hareketsiz, sert, sıcak ve eritemli kitlesi olan 3 yaşında kız çocuğu hastanemize başvurdu. Boynun sol tarafında brankial yarık kisti tanısı alan hasta 6 aylıktan beri düzenli olarak kulak burun boğaz uzmanı tarafından takip edilmekteydi. Apse kültüründe N. meningitidis üredi. Serogrup tayinininde, gruplandırımayan Neisseria meningitidis olarak tanımlandı. N. meningitidis ile ilişkili enfekte brankial yarık kisti nadiren bildirilmiştir ve bilgilerimize göre bu literatürdeki ikinci olgudur. Bu, hastanın yönetiminde mikrobiyolojik tanımlamanın önemli bir rol oynadığını göstermektedir. N. meningitidisín vücudun tüm sistemlerini etkileyen olağandışı klinik bulgularla ortaya çıkabileceği ve bunun da aşı ile önlenebilir hastalıklarda aşılamanın önemine işaret ettiği unutulmamalıdır.

Anahtar Kelimeler: Neisseria meningitidis, brankial yarık kisti, çocuklar

\section{INTRODUCTION}

Meningococcal disease in children, which may present clinically as meningococcemia, as meningitis, or with a mixed picture, is caused by infection with Neisseria meningitidis ( $N$. meningitidis). Unusual manifestations including pneumonia, pharyngitis, pericarditis, endocarditis, conjunctivitis, soft tissue infection, septic arthritis, intraabdominal infection and urogenital infection may accompany meningococcemia or meningitis. Meningococcal disease can rarely occur as a localized infection in the absence of systemic symptoms $(1,2)$.

Branchial cleft cyst is the most common cause of congenital neck pathology in children. One of 
the most common complication of branchial cleft cyst is infection. Typically, neck infections are caused by streptococci, Staphylococcus aureus and anaerobic microorganisms (3). Branchial cleft cyst infections associated with $N$. Meningitidis are uncommon. In this report, we described an unusual case of a 3-year-old patient with infected branchial cleft cyst associated with N. Meningitidis.

\section{CASE REPORT}

A 3-year-old female patient applied to our clinic with one week of swelling and redness of the neck. She had no fever, vomiting or additional symptoms. The patient was diagnosed with branchial cleft cyst in the left side of the neck and regularly followed by an otolaryngologist since 6-month-old. She had a history of applying to the hospital on three different occasions for the same symptoms and improving after treatment with intravenous antibiotics followed by incision and drainage. She had no other medical conditions. On examination at the current admission, the patient had a temperature of $36.7^{\circ} \mathrm{C}$ and a respiratory rate of 20 per minute. The patient's blood pressure was within normal limits. Examination showed no sign of meningeal irritation and stiffness of the neck. Examination of the oropharynx showed no abnormality. She had a tender, immobile, stiff, warm and erythematous mass in the left anterior neck measuring $3 \times 4 \mathrm{~cm}$. No rash was apparent. There were no other relevant physical findings. The complete blood count showed a white blood cell count of $12.100 / \mu \mathrm{l}$ of which $76 \%$ were polymorphonuclear leukocytes; a hemoglobin level of $11.8 \mathrm{~g} / \mathrm{dL}$; and a platelet count of $290.000 / \mu \mathrm{l}$. C-reactive protein value was $64 \mathrm{mg} / \mathrm{L}$ (N:0-5 mg/L). Other basic biochemical tests were normal. An ultrasound examination revealed a $35 \times 40 \mathrm{~cm}$ avascular lesion with cystic changes, adjacent to the upper pole of the thyroid gland. The abscess has drained by a otolaryngologist. Treatment was initiated with clindamycin and ampicilin/sulbactam. The blood culture taken was sterile. No meningococci were grown in the throat swab culture. The abscess culture grew $N$. meningitidis. Serogroup determination identified nongroupable Neisseria meningitidis. Because the patient's physical examination and clinical features showed no signs of meningitis, lumbar puncture was not indicated. The family and close contacts received the appropriate prophylaxis. Clindamycin and ampicilin/sulbactam were discontinued, and the patient was treated with ceftriaxone. Otolaryngology consultation was obtained and surgical intervention was deemed necessary. After 10 days of treatment intravenously, she was discharged home and was to see the Otolaryngology Service for further management of the thyroglossal cyst. Consent was obtained from the patient's parents

\section{DISCUSSION}

Neisseria meningitidis produces a broad spectrum of infections, ranging from the asymptomatic carrier state to fulminant sepsis associated with high mortality and morbidity worldwide. Meningococcal disease presents as meningococcemia, meningitis, or a combination in children. Other less common presentations of invasive disease including tonsillitis, otitis, pneumonia, endocarditis, conjunctivitis, endophthalmitis, soft tissue infection, septic arthritis, osteomyelitis, intraabdominal infection and urogenital infection may accompany meningococcemia or meningitis. Meningococcal disease can rarely occur as a localized infection without associated systemic symptoms $(1,4)$.

Unusual presentations of meningococcal disease in children, which usually present as conjunctivitis or skin and soft tissue infections with associated systemic symptoms, have been reported (5-7). Ferson et al. (5) reported a 9-month-old case presenting with preseptal cellulitis and bacteremia caused by $N$. Meningitidis. In Chand et al.'s (6) study, the case of a previously healthy 4-month-old infant who developed periorbital cellulitis associated with meningococcal meningitis was described. Pediatric cases presenting with an localized infection in the absence of meningococcemia or meningitis are uncommun but have been reported. Jacinto et al. (8) reported a primary meningococcal septic arthritis in a two month-old infant presenting with fever and persistent crying during nappy change. In Gupta et al.'s (9) study, an exceedingly rare case of a 5-monthold female infant diagnosed with primary purulent pericarditis without any clinical evidence of disseminated meningococcemia or meningitis was reported. Cases of 2 patients (9 year-old and 9-month-old) presenting with primary meningococcal conjunctivitis with the absence of a invasive meningococcal infection have been reported $(10,11)$. In this report, we described an infant with brachial cleft cyst and recurrent infections. The abscess culture grew N. Meningitidis, which was an unexpected pathogen. To our knowledge, unusual presentations of $N$. meningitidis infection has rarely been reported in the literature. Our case was considered as an unusual presentation of meningococcal disease.

Branchial cleft cyst is the most common cause of congenital head and neck pathology in children. The most likely complication is recurrent infections. Aerobic, anaerobic and polymicrobial pathogens in the upper respiratory tract and oral cavity (e.g. streptococci, anaerobes, staphylococci and Haemophilus influenza) cause infected branchial cleft cysts. There are a few cases of branchial cleft cysts caused by unusual pathogens in the literature. Gupta et al. (9) reported a 9-year-old boy with a thyroglossal duct cyst abscess associated with Neisseria meningitidis. Patient presented for his third hospital admission with a recurrent neck abscess. The 
abscess was drained; the culture grew $N$. meningitidis and Haemophilus influenzae. Similar findings were also shown reported in our case. This report is the first $N$. Meningitidis case with underlying congenital neck pathology and recurrent infections in the literature.

\section{CONCLUSION}

Unusual microorganisms as well as usual infectious pathogens may cause an infection. This demonstrates the importance of microbiologic identification, which plays a major role in the management of the patient, choosing appropriate treatment, preventing contamination and predicting possible complications. Meningococcal disease have high morbidity and mortality in childhood. It should be noted that $N$. meningitidis can present with unusual clinical manifestations affecting all systems of the body; which indicates the importance of vaccination in vaccine-preventable diseases.

\section{ETHICAL DECLARATIONS}

Informed Consent: Written informed consent was obtained from all participants who participated in this study.

Referee Evaluation Process: Externally peer-reviewed.

Conflict of Interest Statement: The authors have no conflicts of interest to declare.

Financial Disclosure: The authors declared that this study has received no financial support.

Author Contributions: All of the authors declare that they have all participated in the design, execution, and analysis of the paper, and that they have approved the final version.

\section{REFERENCES}

1. Odegaard A. Unusual manifestations of meningococcal infection. A review. NIPH annals. 1983;6(1):59-63.

2. Meningococcal infections. In: Kimberlin DW BM, Jackson MA, Long SS, editor. Red Book: 2018 report of the Committee on Infectious Diseases. 31st ed. ed. Elk Grove Village: American Academy of Pediatrics.; 2018. p. 550-61.

3. Hirshoren N, Fried N, Weinberger JM, Eliashar R, Korem M. The microbiology characteristics of infected branchial cleft anomalies. OTO open. 2019;3(3):2473974X19861065.

4. Hart CA, Thomson AP. Meningococcal disease and its management in children. BMJ. 2006;333(7570):685-90.

5. Ferson MJ, Shi E. Periorbital cellulitis with meningococcal bacteremia. Pediatr Infect Dis J 1988;7(8):600.

6. Chand DV, Hoyen CK, Leonard EG, McComsey GA. First reported case of Neisseria meningitidis periorbital cellulitis associated with meningitis. Pediatrics. 2005;116(6):e874-e5.

7. Patrick CC, Furuta GT, Edwards M, Estabrook M, Blake MS, Baker CJ. Variation in phenotypic expression of the Opa outer membrane protein and lipooligosaccharide of Neisseria meningitidis serogroup C causing periorbital cellulitis and bacteremia. Clin Infect Dis 1993;16(4):523-7.
8. Jacinto T, Rego H, Gonçalves J, Ferreira VP. Primary meningococcal septic arthritis in a two month old infant. Acta Medica Portuguesa. 2015;28(1):117-9.

9. Gupta S, Rudolph G. Cardiac tamponade as a delayed presentation of Neisseria meningitidis infection in a 5-month-old infant. Pediatr Emerg Care 2007;22(3):163-5.

10. Newton DA, Wilson WG. Primary meningococcal conjunctivitis. Pediatrics. 1977;60(1):104-6.

11. Porras MC, Martínez VC, Ruiz IM, et al. Acute cellulitis: an unusual manifestation of meningococcal disease. Scand J Infect Dis 2001;33(1):56-9. 